\title{
ŻYDZI GALICYJSCY W POSZUKIWANIU NOWEJ TOŻSAMOŚCI
}

\author{
Tomasz Gąsowski \\ Uniwersytet Jagielloński w Krakowie
}

\section{ABSTRACT}

\section{GALICIAN JEWS IN SEARCH OF A NEW IDENTITY}

The main cause for identity transformations among Galician Jews were the $19^{\text {th }}$-century modernization processes. They represented a particular challenge to the previous formulas of collective as well as individual life. As they worked in three ways, they produced different effects. In some cases, the challenges of modernity were met not only with a voluntary and positive response, but also with enthusiasm and fascination with the long-awaited "new." In other cases, they were accepted passively, under external and sometimes also internal pressure.

The result of such acceptance was a forced adjustment of one's actions, behavior and forms of existence to the new ways. Finally, the third attitude consisted of a tough and effective resistance, a rejection of the change which could, however, have left certain traces in the mentality of those "relentless." Such position was consistently adopted by the orthodox and the Galician Hasidim. Collective identity, as a sum (not a sequence) of individual identities, is never one-dimensional. Thus, its new elements were an addition to the already existing ones or brought about their further modification. Still, in both cases the effect was a certain new quality. Nevertheless, despite the ongoing transformations, there remained within it a constant component of a cultural character. It determined the overall shape of the identity of Galician Jews, who were different from their fellow believers from Russia, Prussia or even other provinces of the Habsburg Monarchy. Strengthened for almost 150 years, this constant proved more lasting than the country in which it came into being and developed. Galician Jews outlived the Habsburg Monarchy and Galicia itself, cultivating the memory of the old world and their life in it. Both those who stayed in place and those who settled in Palestine or found their new fatherland in the United States, retained, for another generation at least, the elements of Galician identity in various forms.

Key words: assimilation, acculturation, Hasidim, Galicia, identity, Jews

Słowa kluczowe: asymilacja, akulturacja, chasydzi, Galicja, tożsamość, Żydzi 


\section{TOŻSAMOŚĆ SPOŁECZNA}

Pojęcie „tożsamość” jest wieloznaczne. Kryje w sobie różne treści i stanowi obiekt rozległych i wielokierunkowych studiów prowadzonych w obrębie psychologii, socjologii, politologii i kulturoznawstwa; bywa także przedmiotem badań historycznych. Na potrzeby tego artykułu muszę się więc odnieść do tytułowego hasła, ale nie podejmę próby budowania własnej definicji. Zwrócę zatem uwagę tylko na kilka kwestii.

Po pierwsze, w odróżnieniu od tożsamości jednostki, tożsamości indywidualnej, interesuje mnie tożsamość zbiorowa - społeczna, a w niej dwa szczególnie wątki: tożsamość kulturowa oraz narodowa, a raczej tylko pewne, dostrzegalne źródłowo jej elementy. Po drugie, tożsamość zbiorowa, ujmując to najogólniej, oznacza sposób identyfikacji jakiejś grupy z określonym układem kulturowym tworzącym zespół idei, przekonań i poglądów, którym towarzyszą konkretne zwyczaje czy obrzędy współgrające z pewnym, wspólnym dla grupy systemem aksjologicznym i normatywnym. Po trzecie, taka okoliczność działa dwukierunkowo: umacnia spoistość wewnętrzną, zwartość danej grupy, oraz umożliwia jej odróżnianie się od innych grup. Te z kolei będą budowały własny - prawdziwy lub fałszywy - obraz jej tożsamości.

Idźmy dalej. Człowiek jako jednostka należy zwykle do kilku różnych grup społecznych, jego tożsamość tworzy się zatem przez nakładanie kolejnych warstw i wpływów, jakim podlega. Jest tu więc dużo miejsca na indywidualizację tożsamości, ale człowiek jako członek jakiejś grupy musi je, a przynajmniej ich główny trzon, zharmonizować z cechami i normami wspólnymi i charakterystycznymi dla swego otoczenia, wspólnoty, przez którą chce być akceptowany. Trafiają się tu oczywiście wyjątki. Różne ekscentryczne postacie mimo swej widocznej odmienności czy wielobarwności bywają akceptowane przez grupę, gdyż są dla niej użyteczne czy wartościowe.

Tożsamość wreszcie, zarówno jednostkowa, jak i grupowa, ma podwójny wymiar albo - może lepiej powiedzieć - dwa oblicza. Jedno to własne odczucia i samooceny, inaczej: własna wizja wspólnoty. Drugie natomiast stanowi sposób postrzegania nas przez innych, zewnętrznych obserwatorów, czasami neutralnych, czasami partnerów, niekiedy wrogów. Budują oni własny obraz naszej grupy, a następnie posługują się nim. Te dwie oceny mogą być zgodne, zbliżone lub całkowicie sprzeczne, wywołując wówczas dysonans poznawczy z różnymi konsekwencjami tej sytuacji ${ }^{1}$. Wypada też podkreślić, jakkolwiek sam tytuł to sugeruje, że tożsamość nie jest dana raz na zawsze, lecz zmienia się. Zmiana może się zaś dokonywać pod wpływem różnych okoliczności zewnętrznych, ale także wewnętrznych, przebiegać w sposób ewolucyjny albo też gwałtowny, następujący pod wpływem silnych emocji. Może wreszcie stanowić rezultat świadomej decyzji i wysiłków na rzecz jej zrealizowania ${ }^{2}$. Tak też

Szerzej o tym zob. P. Ścigaj, Tożsamość narodowa. Zarys problematyki, Kraków 2012, passim.

2 Zob. Bartłomiej [A. Michnik], Cienie zapomnianych przodków, „Kultura” 1975, nr 5 (332), s. 3-22. 
działo się w przypadku społeczności galicyjskich Żydów. Nierzadkie były przypadki, kiedy po pierwszym, często emocjonalnym okresie fascynacji ideą asymilacji, rozczarowanie prowadziło ich w szeregi syjonistów lub socjalistów. Niekiedy jednak finałem ewolucji stawał się chrzest. Warto pamiętać, że obie wersje tożsamości - wewnętrzna i zewnętrzna - bywały w pewien sposób świadomie kreowane czy budowane i popularyzowane, a nawet mitologizowane.

Badanie współczesnych zjawisk tożsamościowych, jednostkowych czy zbiorowych jest zabiegiem trudnym, często delikatnej natury, naruszającym poczucie intymności jednostek poddanych badaniu, choćby zmuszanych do pewnych deklaracji podczas powszechnych spisów ludności, ale szczególne trudności przedstawia w odniesieniu do przeszłości. Tu nie możemy przeprowadzać wywiadów czy stosować badań ankietowych. Jesteśmy skazani wyłącznie na zachowane przekazy źródłowe, a te $\mathrm{z}$ reguły są nieliczne i niedoskonałe. Tak też jest i w tym, interesującym nas przypadku. Powinny to być przede wszystkim dokumenty typu osobistego: pamiętniki, wspomnienia, korespondencja itp. Tymczasem mamy ich bardzo niewiele, w najlepszym razie pojedyncze materiały tego rodzaju powstały na przełomie XIX i XX wieku, a więc na końcu „klasycznej” epoki galicyjskiej. W tej sytuacji jako materiał źródłowy typu wtórnego w grę wchodzą także: publicystyka, deklaracje ideowe zorganizowanych grup, literatura piękna. Również analiza zachowań, zarówno jednostkowych, jak i zwłaszcza zbiorowych, może dostarczyć pewnej, niezbyt wprawdzie precyzyjnej sugestii w tym względzie. Jednym słowem, będziemy raczej wnioskować na podstawie informacji pośrednich, aniżeli analizować twarde deklaracje tożsamościowe. I jeszcze jedna istotna uwaga natury ogólnej: nośnikiem tożsamości jest pamięć, indywidualna i zbiorowa. Ona gromadzi tożsamość, przechowuje ją i pozwala na jej przekazywanie, co okazuje się sprawą szczególnej wagi w przypadku pamięci społecznej ${ }^{3}$. Użyteczne mogą być zatem także przekazy pochodzące z czasów późniejszych.

$Z$ tej wstępnej refleksji wynika potrzeba wskazania elementów rzeczywistości społecznej, które - moim zdaniem - znacząco oddziaływały na kształt tożsamości Żydów galicyjskich w danym momencie, a zwłaszcza wpływały na jej zmiany polegające na kreowaniu kolejnych, nowych wersji czy odmian. Wymienię tu tylko, bez szerszego rozwodzenia się z braku miejsca, takie czynniki czy też okoliczności, jak religia, a ściślej rzecz biorąc - judaizm jako zintegrowany system religijno-prawny w połączeniu z obyczajem; dalej państwowy, a więc austriacki, oraz krajowy, czyli galicyjsko-polski lub polsko-galicyjski - jak kto woli - system polityczno-prawny; następnie strukturę społeczną; edukację; komunikację przestrzenną i społeczną; służbę wojskową. Lista ta nie jest z pewnością zamknięta.

Wymienione wyżej okoliczności traktowane dynamicznie można w dużym stopniu sprowadzić do jednego podstawowego czynnika, mianowicie wyraźnie przyspieszającej w XIX stuleciu modernizacji, obejmującej - choć w różnym tempie i stopniu - wszystkie sfery życia, a zatem mającej wymiar cywilizacyjny. Przyjmuję więc, że ogólną przyczyną przemian tożsamości galicyjskich Izraelitów były

3 Jan Paweł II, Pamięć i tożsamość, Kraków 2005, s. 65 i n. 
dziewiętnastowieczne procesy modernizacyjne. Stanowiły one swoiste wyzwanie rzucone dotychczasowym formułom życia zbiorowego, a także jednostkowego. Działały one na trzy sposoby i miały różne skutki. Niekiedy odpowiedź na wyzwanie była nie tylko dobrowolna i pozytywna, ale też pełna entuzjazmu i fascynacji „nowym", na które wszak od dawna wyczekiwano. Wyrażała także gotowość wyjścia naprzeciw kolejnym zmianom, artykułowała nawet ich dalszą potrzebę. Inny przypadek to niejako bierna akceptacja przemian pod wpływem zewnętrznej, a czasami także wewnętrznej presji. Następstwem było wymuszone dostosowanie do nich własnego postępowania, zachowania czy form egzystencji. I wreszcie ostatnia sytuacja (która mniej będzie nas tu zajmować) polegała na twardym i skutecznym oporze, odrzuceniu zmian, niekiedy jednak pozostawiających pewne ślady w mentalności tych „nieugiętych”. Taką postawę konsekwentnie prezentowali ortodoksi oraz galicyjscy chasydzi. Te dwa bardzo interesujące, a różniące się pod wieloma względami środowiska ze względu na swoistą hermetyczność niełatwo poddają się obserwacji ${ }^{4}$. Wydaje się jednak, że ich członkowie nie zdołali się całkiem ustrzec przed niektórymi, choć raczej drugorzędnymi nowinkami, dotyczącymi jednak raczej formy niż treści. Przykładem wkraczania modernizacji w świat chasydów jest stosowanie nowoczesnych środków komunikacji społecznej przez konserwatywny krąg cadyka bełskiego Joszuy Rokeacha w latach 80 . XIX wiekus. Trudno jednak wyrokować, czy przyjęcie do wiadomości i - co więcej - korzystanie z niektórych użytecznych wynalazków zewnętrznego świata odciskało jakieś piętno na ich poczuciu zbiorowej tożsamości.

\section{PRZEOBRAŻENIA TOŻSAMOŚCI GALICYJSKICH ŻYDÓW (DO 1914 R.)}

Schyłek, a następnie ostateczny upadek Rzeczypospolitej Obojga Narodów zbiegł się $\mathrm{w}$ czasie ze zmierzchem dotychczasowego feudalnego świata $\mathrm{z}$ jego moralnym i prawnym porządkiem oraz stanową strukturą społeczną. W ówczesnej Europie rodził się nowy porządek. Zaczynała się epoka szeroko rozumianej modernizacji w zakresie ekonomii, stosunków społecznych i politycznych, kultury, czyli po prostu cywilizacji. Zmianom tym torowała drogę myśl europejskiego oświecenia (miała ona też swoistą ,żydowską" wersję w postaci haskali), zaś ich realizację przyspieszyły, a częściowo też wymusiły następstwa Wielkiej Rewolucji Francuskiej. Zainicjowane wówczas procesy biegły następnie - choć w różnym tempie i rytmie - przez całe XIX stulecie; wiek XX przyśpieszył je tylko, wzbogacając o nowe tendencje ${ }^{6}$.

4 Zob. G. Dynner, Men of Silk. The Hassidic Conquest of Polish Jewish Society, Oxford 2006, s. 23 i n.; A. Bartosz, Galicyjskim szlakiem chasydów sądecko-bobowskich, Kraków 2015, s. 7-9.

5 The YIVO Encyclopedia of Jews in Eastern Europe, ed. G. Hundert, vol. 1, New Haven-London 2008, s. 146.

6 Zob. Historie Polski w XIX wieku, red. A. Nowak, t. 1: Kominy, ludzie i obłoki. Modernizacja i kultura, Warszawa 2013, passim. 
W tej to ważnej epoce Żydzi, a raczej Izraelici, bo takie określenie było wówczas powszechnie stosowane, zamieszkujący dotychczas południowe ziemie Rzeczypospolitej (Małopolskę i Ruś Czerwoną) znaleźli się w najdalej na północ wysuniętej prowincji monarchii habsburskiej - w Galicji i Lodomerii. W chwili gdy rozpoczynała się ich blisko półtorawiekowa egzystencja, w gruntownie odmienionych warunkach absolutnej monarchii, dysponowali oni bez wątpienia jakimś rodzajem zbiorowej tożsamości. Wyznaczały ją przede wszystkim religia, język i obyczaj, a ubarwiały - jak sądzę - elementy zrodzone w trakcie kilkuwiekowej egzystencji w Rzeczpospolitej Obojga Narodów i może również jakieś wpływy tożsamości regionalnej (małopolskiej bądź ruskiej) ${ }^{7}$. Nie była ona zatem czystą kartą, co pragnę podkreślić, ale musiała się zmieniać pod wpływem nowych warunków (nierzadko pod przymusem) ${ }^{8}$. Pierwsza faza zmian modernizacyjnych, jaka „musnęla” ludność żydowską zaboru austriackiego, którą od tego momentu będziemy zwyczajowo nazywać - choć może nieco na wyrost - Żydami galicyjskimi, przypadła na ostatnią ćwierć XVIII wieku.

Jednym z ważnych elementów reform epoki józefińskiej, zapoczątkowanych jeszcze przed wstąpieniem na tron cesarza Józefa II, były działania władz administracyjnych w nowej prowincji monarchii, mające (mówiąc najprościej) „ucywilizować” ciemne masy miejscowego żydostwa i stopniowo przekształcać je w lojalnych poddanych cesarza. Działania te nie przyniosły chwilowo większych i trwałych rezultatów. Rozpoczęły jednak proces kreowania „galicyjskich Żydów” na przyszłych „Galicjanerów". Istotną przyczyną niepowodzeń tych pierwszych odgórnych inicjatyw okazały się szybkie postępy ofensywy chasydyzmu na tym terenie. Niemniej ziarno zostało zasiane. Sprzyjało temu przenikanie prądów haskali na ten obszar, nasilające się w pierwszych latach XIX wieku. Pojawiła się zatem, początkowo bardzo wąska, elita Żydów wykształconych w duchu europejskiego liberalizmu (ośrodek tarnopolski Josefa Perla), która lansowała nowe wzorce życia kulturalnego, społecznego, $\mathrm{z}$ czasem także religijnego. Istotny mechanizm służący temu procesowi stanowiły pojawiające się w pierwszych dekadach XIX stulecia nowe formy edukacji młodych Żydów ${ }^{9}$. Konsekwencją zaś było pojawienie się około roku 1820 nowego typu tożsamości, jaskrawo odróżniającego się od obowiązującego dotąd powszechnie dotychczasowego modelu.

Jego istotny składnik stanowiło łączenie dotychczasowej kultury żydowskiej, stopniowo uwalnianej od nadmiaru wątków tradycyjnych, z zastępującą je kulturą europejską w wersji „,wiedeńsko-niemieckiej”. To z kolei dobrze komponowało się z państwowym patriotyzmem, którego najważniejszym punktem odniesienia był dobry cesarz troszczący się o „swoich” Żydów. Zaliczali się do nich galicyjscy

7 Dość powściągliwie wypowiada się w tej materii autor fundamentalnego dzieła na temat historii Żydów na ziemiach polskich Anthony Polonsky, zob. idem, The Jews in Poland and Russia, vol. 1: 1350 to 1881 , Oxford-Portland 2010, s. 471 i n.

8 T.R. Weeks, Jews on the Polish Lands and Polish-Jewish Relations 1795-1914 [w:] Historie Polski XIX wieku, t. 4: Narody, wyznania, emigracje, porównania, Warszawa 2015, s. 67 i n.

9 A. Jakimyszyn, Żydzi krakowscy w dobie Rzeczypospolitej Krakowskiej. Status prawny, przeobrażenia gminy, edukacja, Kraków-Budapeszt 2008, s. 200 i n. 
„maskile”, nazwani z czasem „postępowcami”. Sprzyjał im nieśmiało torujący sobie drogę judaizm reformowany (w latach 40. XIX w. we Lwowie i Krakowie). Oni sami stali się zresztą jego gorącymi rzecznikami ${ }^{10}$.

Ale to jedna, pierwsza i początkowo bardzo wąska ścieżka tworzenia nowej tożsamości. Równolegle do niej, za to z o wiele większym impetem, torowała sobie drogę inna tożsamość, stanowiąca - rzec można - jej przeciwieństwo. Była ona również nowa, co nie oznacza bynajmniej, że nowoczesna w potocznym rozumieniu tego słowa. Gdy pierwsza stała się udziałem elit, druga przyciągała masy. W drugiej połowie XIX wieku na mapie Galicji uformowała się już gęsta sieć wyznaczana przez niewielkie z reguły miejscowości będące siedzibami chasydzkich dynastii i ich dworów. Wokół nich skupiały się kręgi oddanych fanatycznie wyznawców. Pojawiła się nowa, różniąca się znacznie od ortodoksyjnej formuła żydowskiej egzystencji. Nie będziemy w tym miejscu rozwodzić się nad barwnym światem galicyjskich chasydów, opisanym nieźle przez badaczy i odmalowanym przez artystów, także współczesnych. Jest natomiast rzeczą oczywistą, że ich tożsamość różniła się pod wieloma względami, także w sferze religijnej, od naszkicowanej poprzednio. Ale istniał jeden wątek wspólny, który je łączył. To ów „dobry cesarz”. I warto zwrócić uwagę na jeszcze jedną kwestię. Byli to - podkreślam - galicyjscy chasydzi różniący się od tych z pozostałych krain monarchii, a także od tych z zaboru rosyjskiego, dialektem czy wymową, zwyczajami i obrzędami, muzyką.

To stan z połowy XIX wieku. W następnej epoce, w czasach w pełni już uformowanej musilowskiej „Cekanii”, a dla Polaków w erze autonomicznej, ewolucja żydowskiej tożsamości trwała nadal ${ }^{11}$. Istniejące już różnice pogłębiały się, pojawiały się też nowe wzorce. Przede wszystkim zaś nasilał się sam proces zmian tożsamości, odtąd stale rosło jego natężenie. Podstawowym czynnikiem było konstytucyjne równouprawnienie Żydów w austro-węgierskiej monarchii. Wzmocniło to narastające od dłuższego już czasu tendencje emancypacyjne nowych żydowskich elit dążących do uzyskania równouprawnienia ${ }^{12}$. W następstwie zaczął się formalny, a często faktyczny rozpad getta. Jego dotychczasowe istnienie ograniczało, a częściej jeszcze wręcz wykluczało, możliwość istotnej modyfikacji tożsamości członków gettowej wspólnoty. Następowało nieuchronne zetknięcie się jego dotychczasowych mieszkańców ze światem zewnętrznym w stopniu bez porównania szerszym i głębszym niż poprzednio. Rozpoczął się wówczas, narastający odtąd już nieprzerwanie, proces akulturacji. Okoliczności te zmusiły galicyjskich Żydów (owe zjawiska miały wszelako znacznie szerszy wymiar) do częstszego niż poprzednio zadawania pytania, stanowiącego fundament indywidualnego i zbiorowego poczucia tożsamości: kim jestem, kim jesteśmy, a także - kim być chcemy? Ta nowa sytuacja, czyli wspomniane

10 Zob. Synagoga Tempel i środowisko krakowskich Żydów postępowych, red. M. Galas, KrakówBudapeszt 2012, passim.

${ }_{11}$ To literacka kreacja Roberta Musila, zob. idem, Człowiek bez właściwości, wyd. 4, Warszawa 2002, passim.

12 M. Śliż, Galicyjscy Żydzi na drodze do równouprawnienia 1848-1914. Aspekty prawne procesu emancypacji ludności żydowskiej w Galicji, Kraków 2004, s. 14 i n. 
na początku wyzwanie, wymusiła działania na rzecz nowego samookreślenia ${ }^{13}$. Dotychczasowe, w postaci prostej przynależności do Narodu Wybranego, już nie wystarczało. Powoli wprawdzie, ale jednak postępujący coraz śmielej rozwój stosunków kapitalistycznych zaczął stopniowo kruszyć także galicyjskie sztetle, będące swoistą, wschodnioeuropejską materialną formą getta ${ }^{14}$. Przy braku odpowiednio pojemnego rynku pracy na miejscu coraz większego znaczenia nabierały lokalne (tj. wewnątrz monarchii) migracje i późniejsza masowa emigracja za ocean. To również wpłynęło na zmiany tożsamości. W nowych miejscach pracy czy osiedlenia żydowskim wychodźcom z Galicji przypisywano nową tożsamość, z którą musieli siłą rzeczy jakoś się zmierzyć.

Wracając do początków nowej epoki, wypada najpierw odnotować fakt, że w kręgach maskilów, czy też może raczej już postępowców, zwłaszcza w Krakowie włączonym do Galicji dopiero w 1846 roku, zaczęła się formować inna wersja kulturowa ${ }^{15}$. Po raz pierwszy uwidoczniła się ona w okresie Wiosny Ludów i odtąd stale narastała. Wzmocniły ją wydarzenia i emocje związane z powstaniem styczniowym. Oto w obrębie dotychczasowych zwolenników postępu i modernizacji, pozostających przez wiele jeszcze dziesięcioleci w nieustannym zwarciu ze współwyznawcami z kręgów chasydzkich, pojawiła się polska i patriotyczna orientacja. Zaczął się tu (równolegle do Królestwa Polskiego) formować typ Polaka wyznania mojżeszowego lub Żyda polskiego. Stanowiące ich podstawę tożsamości nie były identyczne, lecz pokrewne, zbliżone. Miały bowiem wspólny punkt wyjścia nakazujący zaangażowanie w sprawy kraju i ludzi, wśród których się żyje od pokoleń, oraz poszukiwanie jakichś form integracji z polskością. Czynnikiem odróżniającym stały się natomiast intensywność dążeń do asymilacji oraz wiara w możliwość jej pełnego urzeczywistnienia. W obu przypadkach były one stopniowalne, zmieniały się też pod wpływem zewnętrznych okoliczności (szczególnie istotne okazały się tu polskie reakcje). Mocno łączyło je natomiast przekonanie, że kultura europejska, którą należy poznawać i chłonąć, winna mieć przede wszystkim polską wersję. „Nosiciele” tej nowej tożsamości uznawali również priorytet polskich celów narodowych nad cesarsko-austriackim patriotyzmem, co zresztą niespecjalnie kłóciło się w owych czasach.

Wzmacnianiu takiej właśnie orientacji służyła bez wątpienia autonomia galicyjska z jej daleko posuniętą polonizacją, systemem edukacyjnym, polskimi elitami sprawującymi władzę na miejscu, czyli w „Kraju”, jak potocznie określano wówczas Galicję. Ten wielostronny wpływ musiał oddziaływać na Żydów przy nasilających się formach kontaktów społecznych oraz rosnącej instytucjonalizacji życia zbiorowego, ale pierwotna tożsamość maskilów, zawierająca obfite pokłady austriackiej niemczyzny kulturowej i austriackiej lojalności państwowej, bynajmniej nie znikła.

13 T. Gąsowski, Między gettem a światem. Dylematy ideowe Żydów galicyjskich na przełomie XIX i XX wieku, Kraków 1997, s. 65 i n.

14 N. Sinkoff, Out of the Shtetl. Making Jews Modern in Polish Borderlands, Providence 2004, s. $203-224$.

15 T. Gąsowski, Żydzi krakowscy w drodze do nowoczesności [w:] Budowali nowoczesny Kraków. Żydzi w samorzadzie miejskim, gospodarczym i finansowym miasta (1866-1939), kol. wyd. M. Niezabitowski et al., red. B. Cisowska, Kraków, 2015, s. 27. 
Jej centrum stanowił do lat 80. XIX wieku Lwów, w którym środowisko „Datschen", jak wówczas określano zwolenników takiej orientacji, funkcjonowało nadal bez przeszkód jako elita miejscowego żydostwa ${ }^{16}$. Z czasem jednak nastąpił ogólny odwrót. Ostatnim bastionem dla tej formacji były aż do wybuchu „wielkiej wojny” Brody, uwiecznione w twórczości Josepha Rotha ${ }^{17}$. W wydaniu jednostkowym, indywidualnym, ten typ kulturalnego, wykształconego Żyda galicyjskiego, którego oczy zwrócone były bardziej na Wiedeń niż na Lwów czy potem Warszawę, przetrwał katastrofę I wojny światowej (dla Żydów była to bowiem wyłącznie katastrofa niczego nie zyskali, wiele wycierpieli, niektórzy utracili ojczyznę). Można go było napotkać w licznych większych i mniejszych miejscowościach Małopolski w okresie międzywojennym. Trzeba tu bowiem zaznaczyć, że postępy akulturacji galicyjskich Żydów, dokonujące się od lat 70. XIX stulecia, tylko przez stosunkowo krótki czas 20 lat były równoznaczne z asymilacją. Potem biegły one już oddzielnymi, czasami bardzo rozbieżnymi względem siebie torami ${ }^{18}$.

Nowe zjawiska modyfikujące żydowską tożsamość w Galicji przyniósł koniec XIX wieku wraz z rozwojem ideologii i towarzyszących im nowoczesnych ruchów politycznych ${ }^{19}$. Nie miejsce tu na ich szczegółowe omawianie, trzeba jednak koniecznie zaakcentować dwa z nich ze względu na stosunkowo szeroki rezonans społeczny, dzięki któremu wywierały one znacznie większy wpływ na zmiany tożsamościowe niż poprzednie prądy. Gdy tamte (rzecz jasna, z wyjątkiem chasydyzmu) dotykały raczej elit, te objęły masy. Były to nacjonalizm i socjalizm. Nacjonalizm żydowski to oczywiście syjonizm, który w pierwszych latach XX wieku znalazł w Galicji dobre warunki rozwoju. W wymiarze tożsamościowym oznaczał on, że spora część miejscowych Żydów, zwłaszcza młodych, zaczęła się uważać za przedstawicieli narodu, już nie jak poprzednio Narodu Wybranego, lub też nie wyłącznie w ten sposób, ale jako dumnych ze swego pochodzenia członków narodu żydowskiego mającego prawo do własnego państwa. Wielowiekowa egzystencja ludzi zmuszonych do życia w diasporze (tj. golusie), a więc wśród obcych i na nie swojej ziemi, często cierpiących z tego powodu ucisk i prześladowania, miała się niebawem radykalnie odmienić. Wymagało to jednak wielkiego wysiłku i pracy nad sobą. Należało bowiem stworzyć wzorzec nowego Żyda wyposażonego w narodową, tj. syjonistyczną tożsamość, a następnie w takim duchu kształtować młode pokolenie. Starano się robić to na różne sposoby. Jednym z nich stało się pełne emocji zwalczanie asymilatorów pod hasłem: „Precz z muzykantem Jankielem”. Co istotne, orientacja narodowa stająca się ważnym składnikiem tożsamości była podzielana teraz zarówno przez inteligenckie elity (w Galicji funkcjonowało już wielu jej przedstawicieli), jak też przez

16 K. Muszyńska-Kopff, „Ob Deutsch oder Polnisch” - przyczynek do badań nad asymilacja Żydów we Lwowie w latach 1840-1892 [w:] The Jews in Poland, vol. 1, ed. A.K. Paluch, Cracow 1992, s. 188 i n.

17 J. Roth, Marsz Radetzky'ego, thum. W. Kragen, Kraków 1995, s. 248; zob. też A. Sznajder, Galicja - twórcza inspiracja Józefa Rotha, „Krakowskie Pismo Kresowe” 2014, nr 6, s. 93 i n.

18 Por. T. Andlauer, Die jüdische Bevölkerung im Modernisierungsprozess Galiziens (1867-1914), Frankfurt/Main 2001, s. 26 i n.

19 T.R. Weeks, op. cit., s. 85. 
prostych mieszkańców sztetli, nawet tych pozostających pod wpływem miejscowych cadyków, spajając ich na nowo we wspólnotę na tej syjonistycznej platformie.

Ideologia socjalistyczna w różnych odcieniach okazała się również atrakcyjna, przede wszystkim - jak każda nowinka - dla młodzieży żydowskiej. Rodziła się więc w Galicji, a także oczywiście poza nią, kolejna odmiana tożsamości. Będzie to Żyd-socjalista, albo socjalista żydowski, bo i w przypadku tej nowej tożsamości oba komponenty układały się w różnych proporcjach. Socjalizm w tym wypadku miał nie tylko likwidować konflikty społeczne, ale równocześnie rozwiązać na zawsze „kwestię żydowską", i to od razu na całym świecie. Była to wizja niezmiernie atrakcyjna dla części żydowskich mas.

Pod koniec pierwszej dekady XX wieku pojawił się nowy komponent tożsamości, jakkolwiek jego oddziaływanie ograniczało się do nielicznej grupy młodzieży żydowskiej, przede wszystkim studentów i gimnazjalistów, czyli według ówczesnej nomenklatury akademików i studentów, z rzadka młodych rzemieślników czy robotników. Tworzyły go hasła polskiej irredenty i wywołane przez nie emocje, które prowadziły ich do organizacji o niepodległościowej orientacji, a następnie do Legionów Piłsudskiego ${ }^{20}$.

O Żydach galicyjskich nie można jednak mówić, ograniczając się do Galicji i do okresu zakończonego datą upadku monarchii habsburskiej. Już od lat 80. XIX wieku nasilały się ruchy migracyjne, które prowadziły przede wszystkim miejscową żydowską biedotę („Luftmenschen”) do centrów naddunajskiej monarchii - Wiednia i szybko rozwijającego się Budapesztu ${ }^{21}$. Próbowali oni tam stworzyć dla siebie, a z czasem także dla swych rodzin, warunki do lepszego życia. I tam właśnie w stopniu większym niż dotychczas stali się dla siebie, ale jeszcze bardziej dla innych „Galicjanerami”. Nie była to nazwa pochlebna, bo i przybyszów z tej na poły dzikiej jeszcze, odległej prowincji, jak niekiedy postrzegano w Wiedniu Galicję („Halb-Asien”), nie ceniono zbyt wysoko. W tych niepochlebnych, a często wręcz pogardliwych określeniach celowali zwłaszcza inni współwyznawcy, również galicyjscy Żydzi, którzy zdołali się już wcześniej zadomowić w obu stolicach monarchii Franciszka Józefa. Zaistniała więc kolejna, nowa, nadana im niejako z zewnątrz tożsamość, z którą chcąc nie chcąc - musieli się borykać, żyjąc wśród obcych, a która przylgnęła do nich na długo. Nieco później pojawili się w nowej „ziemi obiecanej”, tj. Ameryce. Niezbyt mile widziani, stworzyli tam - a raczej odtworzyli - własne, chasydzkie wspólnoty religijne, ale także powołali do życia organizację instytucjonalną w postaci Zjednoczonego Stowarzyszenia Żydów Galicyjskich, działającego jeszcze długo po II wojnie światowej ${ }^{22}$.

W ten sposób dotarliśmy do jeszcze jednego aspektu sprawy, a mianowicie „galicyjskiego życia po życiu", a przy okazji trwania elementów galicyjskiej tożsamości.

20 M. Gałęzowski, Na wzór Berka Joselewicza. Żotnierze i oficerowie pochodzenia żydowskiego w Legionach Polskich, Warszawa 2010, s. 19 i n.

${ }_{21}$ M. Pollack, ,Cesarz Ameryki”. Wielka ucieczka z Galicji, thum. K. Niedenthal, Wołowiec 2011, s. 71 i n.

22 L. Wolff, Galicyjscy Żydzi. Mity imperialne i tożsamości prowincjonalne [w:] Mit Galicji, red. J. Purchla, W. Kos, Ż. Komar, M. Rydiger, W.M. Schwarz, Kraków 2014, s. 121-128. 
Wątku tego już nie podejmuję, choć jest on niezmiernie interesujący, zwłaszcza że zdają się mu niekiedy hołdować poważni badacze kreślący historię galicyjskich Żydów do 1941 roku, a także rzecznicy „mitu Galicji”.

\section{REFLEKSJA KOŃCOWA}

Tożsamość zbiorowa, będąca sumą (nie prostą) tożsamości jednostkowych, nie jest nigdy jednowymiarowa. Przedstawiłem wyżej nowe jej elementy będące albo dodatkiem do istniejących już wcześniej komponentów, albo wywołujące ich głębszą modyfikację. Wszelako w obu przypadkach - tak czy inaczej - skutkowały one pewną nową jakością. Nasuwa się jednak istotne pytanie o zakres dokonujących się zmian tożsamości. Próbując szukać na nie odpowiedzi, zaryzykowałbym tezę, że przy wszystkich modyfikacjach pozostał jednak pewien niezmienny, podstawowy jej składnik o charakterze kulturowym, decydujący o istnieniu ogólnej tożsamości galicyjskich Żydów różniących się od współwyznawców z Rosji, Prus, czy nawet pozostałych prowincji monarchii habsburskiej ${ }^{23}$. Umacniany przez blisko 150 lat, okazał się trwalszy aniżeli kraj, w którym się narodził i rozwinął. Galicyjscy Żydzi przeżyli monarchię habsburską i samą Galicję, kultywując pamięć o dawnym świecie i życiu w nim. Zarówno ci, którzy pozostali na miejscu, jak i ci, którzy osiedlili się w Palestynie, i wreszcie ci, których nową ojczyną stały się Stany Zjednoczone, zachowali, przynajmniej przez jeszcze jedno pokolenie, elementy galicyjskiej tożsamości, jakkolwiek w różnorodnej formule. Była to zatem albo złożona tożsamość albo różne tożsamości posiadające wspólny, galicyjski mianownik.

\section{BIBLIOGRAFIA}

Andlauer T., Die jüdische Bevölkerung im Modernisierungsprozess Galiziens (1867-1914), Frankfurt/Main 2001.

Bartal I., The Jews of Eastern Europe 1772-1881, Philadelphia 2005.

Bartłomiej [A. Michnik], Cienie zapomnianych przodków, „Kultura” 1975, nr 5 (332), s. 3-22.

Dynner G., Men of Silk. The Hassidic Conquest of Polish Jewish Society, Oxford 2006.

Gałęzowski M., Na wzór Berka Joselewicza. Żotnierze i oficerowie pochodzenia żydowskiego w Legionach Polskich, Warszawa 2010.

Gąsowski T., Między gettem a światem. Dylematy ideowe Żydów galicyjskich na przełomie

XIX i XX wieku, Kraków 1997.

23 E. Mendelsohn, Żydzi Europy Środkowo-Wschodniej w okresie międzywojennym, thum. A. Tomaszewska, Warszawa 1992, s. 41 i n. 
Gąsowski T., Żydzi krakowscy w drodze do nowoczesności [w:] Budowali nowoczesny Kraków. Żydzi w samorzadzie miejskim, gospodarczym i finansowym miasta (1866-1939), kol. wyd. M. Niezabitowski et al., red. B. Cisowska, Kraków 2015, s. 18-61.

Historie Polski w XIX wieku, red. A. Nowak, t. 1: Kominy, ludzie i obłoki. Modernizacja i kultura, Warszawa 2013.

Jakimyszyn A., Żydzi krakowscy w dobie Rzeczypospolitej Krakowskiej. Status prawny, przeobrażenia gminy, edukacja, Kraków-Budapeszt 2008.

Jan Paweł II, Pamięć i tożsamość, Kraków 2005.

Mahler R., Hassidim and the Jewish Enlightenment. Their Confrontation in Galicia and Poland in the First Half of Nineteenth Century, Philadelphia 1985.

Mendelsohn E., Żydzi Europy Środkowo-Wschodniej w okresie międzywojennym, przeł. A. Tomaszewska, Warszawa 1992.

Musil R., Człowiek bez właściwości, wyd. 4, Warszawa 2002.

Muszyńska-Kopff K., ,Ob Deutsch oder Polnisch” - przyczynek do badań nad asymilacja Żydów we Lwowie w latach 1840-1892 [w:] The Jews in Poland, vol. 1, ed. A.K. Paluch, Cracow 1992, s. 187-203.

Pollack M., ,, Cesarz Ameryki”. Wielka ucieczka z Galicji, thum. K. Niedenthal, Wołowiec 2011.

Polonsky A., The Jews in Poland and Russia, vol. 1: 1350 to 1881, Oxford-Portland 2010.

Roth J., Marsz Radetzky'ego, tłum. W. Kragen, Kraków 1995.

Schulz B., Wiosna [w:] B. Schulz, Sklepy cynamonowe. Sanatorium pod klepsydra, Kraków 1994.

Shanes J., Neither Germans nor Poles. Jewish Nationalism in Galicia before Herzl (18831897), „Austrian History Yearbook” 2003, vol. 34, s. 205-209.

Sinkoff N., Out of the Shtetl. Making Jews Modern in Polish Borderlands, Providence 2004.

Synagoga Tempel i środowisko krakowskich Żydów postepowych, red. M. Galas, KrakówBudapeszt 2012.

Sznajder A., Galicja - twórcza inspiracja Józefa Rotha, „Krakowskie Pismo Kresowe” 2014, nr, 6, s. 93-106.

Ścigaj P., Tożsamość narodowa. Zarys problematyki, Kraków 2012.

Śliż M., Galicyjscy Żydzi na drodze do równouprawnienia 1848-1914. Aspekty prawne procesu emancypacji ludności żydowskiej w Galicji, Kraków 2004.

The YIVO Encyclopedia of Jews in Eastern Europe, ed. G. Hundert, vol. 1, New HavenLondon 2008.

Weeks T.R., Jews on the Polish Lands and Polish-Jewish Relations 1795-1914 [w:] Historie Polski XIX wieku, t. 4: Narody, wyznania, emigracje, porównania, Warszawa 2015, s. 63-114.

Wolff L., Galicyjscy Żydzi. Mity imperialne i tożsamości prowincjonalne [w:] Mit Galicji, red. J. Purchla, W. Kos, Ż. Komar, M. Rydiger, W.M. Schwarz, Kraków 2014, s. $121-128$. 